\title{
Lewenspeil, verlossing van sonde en MIV en VIGS in Suider-Afrika: Gedagtes uit die Gereformeerde tradisie
}

\author{
Montagu Murray (ISWEN) ${ }^{*}$ \\ Departement Dogmatiek en Christelike Etiek \\ Universiteit van Pretoria
}

\begin{abstract}
Standard of living, forgiveness of sins and HIV/aids in Southern Africa: Notions from the Reformed tradition The article reflects on the relation between standard of living and forgiveness of sins by examining a few significant perspectives from the Reformed tradition. The contemplation results in the invention of a B\&S-SCHEME (beggar-and-sinner scheme) recommended by the author as an aid to a more nuanced reflection on theological propositions concerning the relationship between standard of living and the forgiveness of sins. In conclusion, theological propositions on the relationship between a person or group's HIV-status and guilt and/or innocence before God are examined as an illustration of the application possibility of the B\&SSCHEME.
\end{abstract}

\section{INLEIDING}

\subsection{Probleemstelling}

'n Groeiende kloof word die laaste dekades wêreldwyd tussen ryker en armer lande, sektore en individue in die samelewing waargeneem (Bosch 1991:2-4; Nürnberger 1999:39-69; Nyerere 1995:415-417). Hierdie gapende kloof is op

\footnotetext{
* Hierdie artikel is gebaseer op die DD-proefskrif van M Murray, getitel "Troos vir bedelaar en sondaar: ' $n$ Teologies-Kritiese ondersoek na die verband tussen lewenspeil en verlossing van sonde in die Gereformeerde tradisie en die betekenis daarvan vir 'n Christelike lewenstyl in Suider-Afrika." Die proefskrif is voorberei onder promotorskap van prof dr Conrad Wethmar, Departement Dogmatiek en Christelike Etiek, Fakulteit Teologie, Universiteit van Pretoria (2003).
} 
'n besondere wyse sigbaar in Pretoria, Suid-Afrika, waar ek tans woon en werk. Binne ' $\mathrm{n}$ radius van $10 \mathrm{~km}$ is spogwoonbuurte in die ooste van Pretoria, sowel as armer, informele gebiede aan die buitewyke van Pretoria, geleë.

Suid-Afrika word nie alleen gekenmerk deur'n gapende kloof tussen ryk en arm mense nie. Suid-Afrikaners worstel boonop daarmee om die nalatenskap van die politieke stelsel van Apartheid te verwerk. Verskeie individue en kerkgroepe het Apartheid as sonde bely. Twee verskynsels is dus op 'n besondere wyse aanwesig in die Suid-Afrikaanse samelewing: 'n buitensporige groot verskil in lewenspeil tussen mense en skuld oor gesistematiseerde onreg.

Die verband tussen lewenspeil en skuld met die kenmerkende ras en klaspolitieke ondertoon wat dit in die Suid-Afrikaanse konteks het, is hiermee aan die orde gestel. Hierdie artikel is egter nie in die eerste plek daarop toegespits om die Suid-Afrikaanse rasse of klasse politiek te ontleed nie. Die bedoeling is eerder om vanuit ' $n$ sistematies teologiese hoek te vra watter bydrae die teologie kan lewer om die verband tussen lewenspeil en verlossing van sonde beter te verstaan. Belangrike werke van 'n aantal teologiese gespreksgenote word daarom bestudeer om ondersoek in te stel na die argumente wat veral deur Gereformeerdes gebruik is om oor hul lewenspeil en lewenstyl voor die aangesig van God te praat.

Die besinning lei uiteindelik daartoe dat 'n skema voorgestel word om teologiese stellings wat betrekking het op die verband tussen lewenspeil en verlossing van sonde te analiseer. Die skema is ' $n$ poging om ' $n$ hermeneutiese instrument aan te bied wat kan help om klemtone raak te sien in die argumente wat mense gebruik om hulle lewenspeil in hul verhouding tot God te verantwoord. Dit sou vir die ontleding van die meeste teologiese stellings wat lewenspeil en eskatologiese heil op mekaar betrek, gebruik kon word. Eerder as om op teologiese stellings met betrekking tot sake soos restitusie of regstellende aksie in Suid-Afrika in te gaan, word in hierdie artikel gekies om die gebruikswaarde van die instrument te illustreer deur na teologiese stellings oor mense met MIV en vigs te verwys. MIV en vigs het met beide lewenspeil en verkeerde lewenstylbesluite te make. Die bedoeling is om aan te toon dat die sistematiese teologie - miskien uit 'n ietwat ongewone hoek kan help dat daar meer genuanseerd en met groter versigtigheid verbande gelê word wanneer die oorsake van MIV en vigs met lewenspeil of skuld verbind word.

\subsection{Opbou van die betoog}

Die inhoud van die Nederlandse teoloog, Noordmans, se meditasie Zondaar en bedelaar word eerstens onder die loep geneem aangesien dit die 
hartsnaar van die problematiek rakende die verband tussen lewenspeil en skuld teologies aanroer.

Vervolgens word Calvyn se drie algemene riglyne uit die Skrif vir die regte gebruik van aardse hulpmiddele behandel vanweë hierdie artikel se toespitsing op die Gereformeerd-teologiese standpunt. Die blik op Calvyn se siening help om die kritiek wat Noordmans in Zondaar en bedelaar teen Pierson en die Heidelbergse Kategismus Sondag 10 lewer, in perspektief te plaas.

Ná Calvyn word Kuyper en Gutiérrez as eksponente van onderskeidelik die neo-Calvinisme en die Bevrydingsteologiese tradisies aan die orde gestel. Beide hierdie tradisies bied diepsinnige, eiesoortige analises van die kontemporêre samelewing, wat 'n brug kan vorm tussen Calvyn en die perspektiewe van die Suid-Afrikaanse teoloë Heyns, Bosch en Mofokeng.

Die onderskeie sieninge van al die gespreksgenote gee aanleiding tot die ontwikkeling van 'n bedelaar-en-sondaar-skema (B\&S-SKEMA). Hierdie skema poog om 'n raamwerk aan te bied met behulp waarvan daar meer genuanseerd omgegaan kan word met teologiese stellings oor die verband tussen lewenspeil en die verlossing van sonde. As voorbeeld van die toepassing van die B\&S-SKEMA word daar telkens 'n paar opmerkings gemaak oor die wyse waarop teologiese stellings oor mense met MIV en vigs in Suider-Afrika meer genuanseerd bedink sou kon word.

\section{DIE MEDITASIE ZONDAAR EN BEDELAAR}

\subsection{Die belang van die meditasie}

Berkhof skryf dat Noordmans se teologie in Zondaar en bedelaar so radikaal en profeties word dat dit ver bo sy eie tyd uitstyg: "In november 1945 schreef hij zijn opstel Zondaar en bedelaar, waarin een zo radicale verbinding van het Evangelie met de armen wordt gelegd als mijns inziens in onze tijd van 'theologie van de bevrijding' nog niet is geëvenaard" (Berkhof 1981:160). Dit is nodig om die inhoud van Noordmans se meditasie deeglik te bestudeer om Berkhof se opmerking te verstaan.

\subsection{Die inhoud van die meditasie}

Noordmans begin sy meditasie deur daarop te wys dat beide die gelykenisse in Lukas 18:9-14 (die Fariseër en die tollenaar) en Lukas 16:19-31 (die ryk man en Lasarus) heel bekend is. Die gelykenis oor die sondaar (Luk 18) het egter meer aktueel geword, omdat ons dadelik besef dat dit oor onsself gaan. In die geval van die bedelaar (Luk 16) dink ons eerder aan iemand anders. God het egter volgens Noordmans aan die gelykenis van die ryk man en 
Lasarus 'n toepaslikheid gegee, wat vele van ons tot mistieke ervaring bring. Dit blyk dat liggaamlike nood nouer verbind is aan saligheid as wat ons gemeen het. En dit is minder vreemd as vroeër dat die bede om daaglikse brood in die Onse Vader vóór vergewe ons ons skulde staan, net soos die gelykenis van die bedelaar in Lukas 16 vóór dié van die sondaar in Lukas 18 aangetref word (Noordmans 1980:15).

Noordmans gebruik die bundel Gelykenissen des Heeren van $\mathrm{H}$ Pierson as vertrekpunt vir sy oordenking (Pierson 1891). Pierson ontken dat Lasarus in Abraham se skoot opgeneem word omdat hy arm was. Armoede is 'n natuurlike toestand, soos gesondheid en siekte, reën en sonskyn, vrugbare en onvrugbare jare. 'n Mens kan volgens Pierson in voorspoed dankbaar en in teëspoed geduldig wees en in beide gevalle as kind van God. Hierdie dinge lê op die terrein van die voorsienigheid en raak nie die middelpunt van die evangelie nie. Armoede is vir Lasarus ' $n$ kruis, maar die kruisdra self bring hom nie nader aan die hemel nie. Rykdom is 'n gevaar, maar dit is nie 'n versoeking van die bose wat op die hel uitloop nie. Teenoor die jaloerse arme plaas Pierson die tevrede Lasarus. Die ryk man word 'n les vir die rykes en Lasarus 'n les vir die armes. Hierdeur gaan die evangelie vir die arme en die oordeel oor die ryke volgens Noordmans verlore.

Met die gelykenis van die Fariseër en tollenaar is dit anders gesteld. Alle Fariseërs word gebrandmerk en saam met die tollenaar soek elke sondaar saligheid. Fariseër het 'n skeldwoord geword onder gelowiges en tollenaar'n titel wat reg gee op die Koninkryk van God (Noordmans 1980:16).

Noordmans sien tussen die figure in die gelykenis in Lukas 16 reeds in hierdie lewe 'n kloof. Die kloof is deur die voorsienigheid geskape omdat dit gevaarlik sou wees as beide by mekaar betrokke raak soos Fariseër en tollenaar. Want die gevolg daarvan dat die Fariseër en tollenaar dialekties op mekaar kon inwerk, is dat Fariseërs nie meer te vinde is nie. Maar rykes het nie verdwyn uit angs vir die hel nie en daar het geen toeloop tot armoede as voorpoort van die hemel ontstaan nie (Noordmans 1980:17-18).

Lasarus glo met sy swere en getuig lewenslank met sy bestaan dat hy 'n skat in die hemel het, terwyl die tollenaar dit slegs in 'n oomblik met die mond bely.

In beide gelykenisse kry ons die Heidelbergse ellende, verlossing en dankbaarheid. Die evangelie van die arme kan egter nie in die verlossing 'n stuk opneem soos Sondag 10 van die Heidelbergse Kategismus waarin rykdom en armoede in een asem genoem word met reën en droogte nie. Wanneer armoede op hierdie wyse as iets natuurliks voorgestel word, verloor die evangelie sy krag (Noordmans 1980:21-23). 
Die arme sondaar, die tollenaar, het met God as Regter te doen. Die arme bedelaar, Lasarus, het met God as Skepper te doen, wat arme en ryke gemaak het. Dit lyk asof die gelykenis van die verlore seun in Lukas hierdie twee gelykenisse sou kon verbind, want daar het ons te doen met 'n arme bedelaar, wat tegelyk ' $n$ arme sondaar is. Maar armoede is in die geval van die verlore seun, volgens Noordmans, die gevolg van eie sonde en kom met dié van Lasarus in geen enkele opsig ooreen nie. Dit moet dien as prikkel tot sondebesef. By Lasarus sluit die ellende egter 'n skuldbewussyn uit (Noordmans 1980:24-25).

Ons mag nie van Lasarus eis om eers te oefen om die bede van die tollenaar te stamel nie. In hoeverre uitwendige ellende, die nood van die lewe, die armoede, 'n innerlike keersy van skuldbesef kan of moet hê, skryf Noordmans, is nie vir ons om te besluit nie (Noordmans 1980:25).

\section{CALVYN}

Calvyn se uiteensetting van die wyse waarop gelowiges aardse hulpmiddele behoort te gebruik in sy Institusie, staan in noue verband met die tersaaklike vraag na die verband tussen lewenspeil en die verlossing van sonde in die Gereformeerde tradisie wat deur Noordmans se meditasie aan die orde gestel is. Calvyn se siening kan lig werp op Noordmans se kritiek teen die Voorsienigheidsleer van Pierson en die Heidelbergse Kategismus, Sondag 10 in Zondaar en bedelaar.

\subsection{Drie algemene riglyne uit die Skrif}

Calvyn is versigtig om die gewete aan vasgestelde reëls te bind wanneer dit handel oor die vraag na die regte gebruik van aardse hulpmiddele. Dát die Skrif algemene riglyne gee aan die hand waarvan ons selfondersoek kan doen, is egter nie te betwyfel nie (Calvyn Inst, III, x, 1). Drie sake moet bedink word en as riglyne eerbiedig word: Die doel waarmee God voedsel geskape het, die ewige lewe en rentmeesterskap.

\subsubsection{Die doel waarmee God voedsel geskape het}

Wie bedink dat God voedsel geskape het, kan dankbaar en met 'n skoon gewete die goeie gawes wat Hy tot ons welsyn gemaak het, met matigheid geniet. $^{1}$

Hoogmoed en skynheiligheid kan 'n mens laat vergeet waarom God voedsel geskape het. Ryk mense behoort versigtig te wees om nie, deur

\footnotetext{
${ }^{1} \mathrm{Vgl}$ Institutes III, x, 2 and 3; III, xix, 8 and 9; Commentaries on Gn 1:28; Ps 23:5; Ps 36:8; Ps 104:15; Am 5:11; Am 6:4; Am 8:11; 1 Cor 6:12; 1 Cor 6:13; 1 Cor 10:25; 2 Cor 9:10; 2 Tm $1: 7$; Ja $5: 3$.
} 
hoogmoed bedwelm, hulle te vergryp aan genot en geweld nie. Trotse mense vergeet maklik dat ware rykdom die seën van God is. ${ }^{2}$ Aan die anderkant moet die onmenslike filosofie - wat die gewetens van gelowiges met strenger bande as Gods Woord wil bind en leer dat armoede die enigste poort tot die hemel is - vermy word. Hierdie filosofie loop die gevaar om skynheilig te raak wanneer iemand armoede verkondig, maar sélf genoeg het om te eet en nie 'n vinger verroer om iets te vervaardig sodat die nood van die armes verlig kan word nie. ${ }^{3}$

\subsubsection{Die ewige lewe}

Wie die hemelse onsterflikheid bedink, kan die wêreld gebruik asof dit nie gebruik word nie en geduldig lyding verdra. ${ }^{4}$ Ons moenie suinig vasklou aan ons verganklike besittings tot selfbehoud nie. Uit dankbaarheid behoort ons sover ons vermoë dit toelaat, volgens die reël van die liefde, aan die behoeftiges medelye te bewys. ${ }^{5}$ In tye van ellende en verdrukking kan ons geduldig bly, want ons weet God teister ons met rampe tot ons saligheid. ${ }^{6}$

\subsubsection{Rentmeesterskap}

Met die krag wat God gee, behoort gelowiges (en die owerheid!) die roeping wat Hy aan ons opgedra het in gehoorsaamheid teenoor Hom uit te voer. ${ }^{7}$ Wie gehoorsaam aan God is, kan onbevrees met 'n skoon gewete alles wat

\footnotetext{
${ }^{2}$ Vgl Institutes I, xvii, 9; II, viii, 46 and 49; III, vii, 8; III, viii, 2; Commentaries on Gn 13:1 and 10; Dt 15:1 Dt 24:10; Ps 10:2, 5 and 6; Ps 35:10; Ps 62:10; Am 2:6 and 7; Am 3:9 and 15; Am 4:1; Am 5:11; Am 6:1, 4 and 5; Mt 4:4; Mt 19:23; Lk 12:13-21; Ac 4:32 and 34; 1 Cor 6:12; 2 Cor 8:3; 2 Cor 15:32; $1 \mathrm{Tm} \mathrm{6:8} \mathrm{and} \mathrm{9;} \mathrm{Ja} \mathrm{2:1} \mathrm{and} \mathrm{6;} \mathrm{Ja} \mathrm{4:2;} \mathrm{Ja} \mathrm{5:2,} 3$ and 4; Sermons on Dt 5:9 [CO XXVI, 346-358]; Is 53:9-10 [CO LI 513].
}

${ }^{3}$ Vgl Institutes III, x, 1; III, xix, 7 and 9; III, xix, 12; Commentaries on Gn 13:1; Ac 2:44; 1 Cor 6:12; 1 Cor 9:27; 1 Cor 10:23 and 25; 1 Cor 13:3; 2 Cor 8:11; 2 Tm 1:7.

${ }^{4}$ Vgl Institutes I, v, 10; I, xvii, 10; I, xvii, 11; III, viii, 1; III, ix, 1, 2, 3, 4, 5, and 6; III, x, 4; Commentaries on Ps 10:5 and 6; Ps 62:10.

${ }^{5}$ VgI Institutes II, viii, 55; III, vii, 5 and 7; III, x, 4; III, xix, 12 and 13; Commentaries on Gn 13:1 and 11; Ex. 22:25; Dt 15:1, 3 and 7; Dt 24:10; Am 6:5; Ps 112:5 and 9; Mt 19:16-31; Mt 25:20; Ac 2:44; Ac 4:34; Ac 5:1; 1 Cor 6:12; 2 Cor 8:1, 2, 4, 8-11 and 15; 2 Cor 9:6-8 and 10.

${ }^{6} \mathrm{VgI}$ Institutes I, v, 7 and 9; I, xvi, 2-4 and 6; I, xvii, 4, 8 and 11; II, vi, 1; II, viii, 1; III, viii, 1-11; III, ix, 1; III, x, 5; Commentaries on Gn 1:16; Gn 3:19; Gn 13:5; Dt 24:10; Ps 9:18; Ps 10:5 and 6; Ps 12:5; Ps 34:19; Ps 78:18; Ps 62:10; Ps 141:4; Am 3:6; Am 4:1; Am 5:18; Am 6:1 and 4; Am 8:11; Mt 19:16; Lk 16:19-31; 2 Cor 8:2; Ja 2:5; Ja 5:5; Sermon on Dt 5:19 [CO XXVI, 346358]; Letter to Church of Aix [CR 3379].

\footnotetext{
${ }^{7}$ VgI Institutes III, viii, 9; III, x, 6; III, xx, 44; III, xxiv, 1-8 and 17; IV, xx, 1, 2, 9, 15 and 20; Commentaries on Gn 3:17-19; Am 4:1; 2 Cor 8:15; Ac 4:32; Ja 1:9.
} 
die liefdevolle Vader voorsien in geloof van Hom ontvang. ${ }^{8}$ Wie op God vertrou, kan sober en vrygewig lewe in oorvloed en gebrek kalm en lydsaam verdra. $^{9}$

\section{STEMME UIT DIE NEO-CALVINISME EN DIE BEVRYDINGSTEOLOGIE}

Die sosiale samestelling van die bestel waarin Calvyn gewoon en gewerk het, verskil in vele opsigte ingrypend van ons hedendaagse maatskappy. Dit is daarom nodig om gespreksgenote te betrek wat sou kon help om 'n brug te vorm tussen Calvyn se sieninge oor die Christelike houding ten aansien van die gebruik van aardse hulpmiddele en die Suid-Afrikaanse Gereformeerde teologiese refleksie oor die verband tussen lewenspeil en die verlossing van sonde.

Wolterstorff (1981:43) meen dat beide die neo-Calvinisme en die Bevrydingsteologie diepsinnige analises van die kontemporêre samelewing bied, gepaard met 'n omvattende Christelike beskouing op die geskiedenis en die maatskappy. Beide die neo-Calvinistiese en Bevrydingsteologiese tradisies het ' $n$ besondere invloed op die Suid-Afrikaanse gespreksgenote wat later in hierdie artikel betrek word, uitgeoefen.

Vir Kuyper (1891:5) - wat as eksponent van die neo-Calvinistiese inslag beskou sou kon word - gaan die sosiale kwessie daaroor dat die teenswoordige toestand onhoudbaar geword het omdat die grondslag van ons maatskaplike gebou aangetas is.

Die hele Sosiale vraagstuk word na Kuyper se mening gebore uit die verband tussen ons menslike lewe en die stoflike wêreld wat ons omring. Daarom gaan hy van die teenstelling tussen natuur (wat onafhanklik van die wil van die mens bestaan) en kuns (wat op die natuur inwerk) uit. Daar sou enersyds gesê moet word dat die menslike kuns ons uit'n toestand van barbarisme bring tot in 'n geordende samelewing, maar andersyds kan die kuns - waar dit ontaard - verhoudings vergiftig en ellende veroorsaak (Kuyper 1891:11-12).

Die diepste oorsaak van mense se ontaarding lê daarin dat hulle nie reken op hul ewige bestemming nie. Die Franse Revolusie het die ewige lewe

\footnotetext{
${ }^{8}$ Institutes I, xvi, 7-9; I, vii, 1-5 and 11-13; I, xviii, 1; II, vi, 1; II, viii, 45-46; III, vii, 4 and 9; III, viii, 11; III, x, 5; III, xix, 9 and 16; III, xx, 2 and 44; Commentaries on Gn 2:26 and 28; Dt 15:11; Am 3:6; Am 4:1; Ps 10:1, 4-6 and 14-15; Ps34:19; Ps 36:8; Mt 6:11; Phlp 4:11; 1 Th 4:6; Sermon on Dt 5:19; Cathechism 1938, 25.

${ }^{9}$ Institutes I, xvii, 4 and 7; III, vii, 3; III, x, 4; III, xix, 9; Commentaries on Gn 13:9; Dt 15:1; Am 4:1; Am 6:1; Ps 23:5; Ps 104:15; Ps 106:14; Ps 112:5; Mt 19:16; Lk 16:19-31; Jn 11:33; Ac 2:46; 1 Cor 6:12 and 19; 1 Cor 9:24-25; 2 Cor 8:15; 2 Cor 9:10; Phlp 4:12; 1 Th 4:13; 1 Th 5:16; 1 Tm 6:7-8; 2 Tm 1:7; Ja 4:1; Ja 5:5.
} 
as horison afgesny en so is die struggle for money ingelei as noodwendige uitvloeisel van die struggle for life, wat die wet in die dierewêreld is. Die uiteinde van hierdie toestand is dat daar besitters van miljarde aan die eenkant en ellendige bedelaars aan die anderkant ontstaan (Kuyper 1891:21). Die ontaarding het ingetree omdat daar nie eerbied is vir die belydenis dat God, die Skepper van alle dinge, oor alles in die werklikheid soewerein is nie. Alle soewereiniteit is aan Jesus gegee om onderskeie samelewingsverbande te bevry en te besiel en aan hulle soewereiniteit in eie kring te verskaf (Kuyper $1880: 35) .^{10}$

Waar Kuyper benadruk dat gelowiges met hul hele lewe voor die aangesig van die soewereine God staan, beklemtoon Gutiérrez (1988) - wat as eksponent van die Bevrydingsteologiese inslag beskou sou kon word God se besondere sorg vir armes en onderdruktes.

Bevrydingsteologie het vir Gutiérrez (1988:xx;xxvii-xxviii) te make met die wyse waarop, in die lig van die verkondiging van die Koninkryk van God, die stryd van die armes en onderdruktes vír geregtigheid en téén onreg opgeneem word en hulle perspektief teologies gestel word. Armoede is 'n komplekse menslike toestand en daarom kan aanvaar word dat die oorsake van armoede ook kompleks is. Maar dit word volgens Gutiérrez al duideliker dat die gebrek aan ontwikkeling in ontwikkelende lande gesien moet word as 'n produk van die verhouding tussen ryker en armer lande. Die situasie beloof ook nie om stelselmatig deur die ontwikkeling van agtergeblewe ekonomieë te verbeter nie. Die opheffing van armoede deur ontwikkeling kan juis nie plaasvind binne die huidige bestel van privaatbesit waarin die besitters sorg dat die werkersklas afhanklik bly nie. 'n Begrip soos ontwikkeling verdiskonteer nie hoe rykes deur geïnstitusionaliseerde geweld armes onderdruk nie: "In this light, to speak about the process of liberation begins to appear more appropriate and richer in human content. Liberation in fact expresses the inescapable moment of radical change which is foreign to the ordinary use of the term development" (Gutiérrez 1988:17).

\footnotetext{
${ }^{10}$ Die betekenis van Christus se soewereiniteit oor elke aspek van die menslike bestaan en die wyse waarop die Calvinistiese tradisie die konsekwensie van hierdie belydenis in leer en lewe geïnternaliseer het, word in 1898 deur Kuyper in sy welbekende Stone-lesinge by Princeton in Amerika uitgewerk. Die grondgedagte van Calvinisme is vir Kuyper dat ons met ons hele lewe voor Gods aangesig staan. Sy analise is in ses lesings uiteengesit: Die Calvinisme en die geskiedenis, die Calvinisme en die geloof, die Calvinisme en die staatkunde, die Calvinisme en die wetenskap, die Calvinisme en die kuns en laastens, die Calvinisme en die toekoms (Kuyper 1959).
} 


\section{SUID-AFRIKAANSE TEOLOË OOR DIE VERBAND TUSSEN LEWENSPEIL EN DIE VERLOSSING VAN SONDE}

Vir Heyns (1986:89) lê die wese van die etiese nie in 'n aangeleerde vaardigheid of die ontwikkeling van die menslike persoonlikheid nie. Dit is persoonsbehandeling wat begrond word in die skeppingswil van God. Die Christelike etos gaan oor die antwoord-in-lewenstyl op die handelinge van God (Heyns 1986:44).

Heyns kies om aan die hand van ses samelewingsverbande die sosiale etiek in oënskou te neem: Die huwelik, gesin, kultuur, volk, kerk en staat. Volgens Heyns vind die "differensiasie in 'n verskeidenheid samelewingsverbande" plaas op grond van die "deur die Voorsienigheidswoord geïnisieerde positiveringsarbeid van die mens van die moontlikhede en die wetmatighede wat in die skepping aanwesig is" (Heyns 1989:17). In elke samelewingsverband het 'n mens 'n bepaalde funksie, maar in al die samelewingsverbande behoort gelowiges op te tree as burgers van die Koninkryk van God (Heyns 1986:20). As burgers van die Koninkryk soek gelowiges na die lewende en heersende en uitdelende Koning. Daarteenoor is ongelowiges "primêr gewikkel in 'n stryd om lewensmiddele; die produksie en die konsumpsie daarvan en die konkurrensie in die stryd daarom" (Heyns 1986:58). Maar die populêre voorstelling soos in sommige variasies van die Bevrydings-teologie aangetref word dat die Skrif by voorbaat téén die rykes en vír die armes is, verstaan volgens Heyns die boodskap van die Bybel verkeerd. Ryk mense soos Abraham, Jakob, Josef, Salomo en Job, word vir hulle geloof geprys en het deel aan Gods guns. Wanneer rykes gekritiseer word, is dit nie vanweë hulle rykdom nie, maar vanweë hulle ongeloof in God en vanweë hulle uitbuiting van die armes: "Die oplossing is nie dat rykes armer word en armes ryker word nie, maar dat almal gelowiges word, want dan sal - idealiter (sic) - daar nie meer die probleem van rykdom en armoede voorkom nie" (Heyns 1986:270).

In Heyns se geval sou die verhouding tussen die sondaar en die bedelaar teen die agtergrond van sy begronding van die etiese in die skeppingswil van God verstaan kon word. By Bosch ontmoet sondaar en bedelaar mekaar in die spanningsvolle speelveld tussen die alreeds - en die nog nie-dimensies van die Koninkryk van God.

Volgens Bosch veroorsaak die spanning tussen die kerk se wese en die empiriese situasie waarin die kerk verkeer dat die kerk altyd in 'n krisissituasie bestaan (Bosch 1991:2). Die krisissituasie waarin die kerk tans lewe, word vererger deur wetenskaplike en tegnologiese vooruitgang en daarmee gepaardgaande wêreldwye sekularisering wat vir baie mense geloof in God 
oorbodig maak. Die groeiende gaping tussen ryker en armer dele van die wêreldbevolking blaas die krisis verder aan. Vanweë die Westerse wêreld se noue verbintenis met die genoemde vooruitgang bevind Westerse mense (insluitend Christene in die Westerse wêreld) hulle grotendeels aan die kant van die kloof wat materiële welvaart geniet. Westerse Christene ly toenemend aan 'n skuldgevoel vanweë hulle groter wordende rykdom en baie arm Christene is gefrustreerd met die fisiese lyding waaraan hulle daagliks onderworpe is (Heyns 1986:3-4).

Mofokeng (1983:10-12) wys net soos Bosch op die groeiende kloof tussen ryk en arm mense. Hy voer aan dat probleme in die Suid-Afrikaanse samelewing soos onderdrukking, armoede, grondonteiening en diskriminasie nie alleen materiële probleme is nie. Dit het te doen met die menslike bewussyn - die onderdrukker en onderdrukte se ingesteldheid en lewenstyl.

In die verlede is die swartman in Suid-Afrika gesien as 'n sondaar bloot omdat hy swart is (Mofokeng 1983:15). Dit is na Mofokeng se mening onder andere te wyte aan die missionêre Christendom wat die swart kultuur en gemeenskap as demonies gesien het. Swartmense is beskou as heidene wat bekeer moes word (Mofokeng 1989:46). Stelselmatig is swartmense vervreem van hulle geskiedenis, hulle kultuur en hulle land (Mofokeng 1983:21-22).

\section{Die B\&S-SKEMA}

Vervolgens word 'n B\&S-SKEMA (Sien tabel 1, 2 \& 3) aangebied om teologiese stellings oor die verband tussen lewenspeil en die verlossing van sonde te analiseer. Verskillende klemtone by die onderskeie gespreksgenote het gehelp om die skema te ontwikkel. Terselfdertyd kan die skema ook gebruik word om teologiese stellings wat deur die gespreksgenote gemaak word te analiseer. Die bedoeling van die skema is uiteindelik - met in agname van die gevare en beperkinge verbonde aan die gebruikmaking van 'n skema - om 'n hulpmiddel te wees om teologiese stellings wat verband hou met lewenspeil en die verlossing van sonde te ontleed.

Met teologiese stelling(s) word bedoel een of meer sin, argument, uitspraak, opmerking, opinie of mening wat 'n teologiese karakter dra, dit wil sê, waarin die persoon en werk van God en die verhouding tussen God en die mens aan die orde gestel word. Stellings oor 'n persoon of groep se MIVstatus en skuld en/of onskuld voor God word onder elke punt van bespreking kortliks ontleed as voorbeeld van die gebruik van die B\&S-SKEMA.

\subsection{Identiteit}

"Identiteit" het te make met die antwoorde op vrae soos: Wie maak die teologiese stelling? Oor wie word die stelling gemaak? Namens wie word die 
stelling gemaak? Met wie identifiseer die persoon wat die stelling maak? Watter persepsies verraai die persoon wat die stelling maak oor sy of haar siening van God of van die mense oor wie die stelling handel?

Dit is eerstens belangrik om te bepaal wie ' $n$ bepaalde teologiese stelling oor die verband tussen lewenspeil en die verlossing van sonde maak en oor wie die stelling gemaak word. Dit is byvoorbeeld nie dieselfde om jou eie verhouding met God te interpreteer as om 'n oordeel oor 'n ander se verhouding met God te vel nie.

Wanneer Guitiérrez of Mofokeng die stelling maak dat God aan die kant van die armes is (God's preferential option for the poor), dan is dit 'n stelling waarin God as subjek ' $n$ keuse uitoefen ten gunste van die arme as objek. Die toonaard van die Bevrydingsteologiese en Swart Teologiese aanspraak op God se besondere sorg vir die arme is oorwegend juridies: God as Regter kies vír die arme téén die ryke ... vír die onderdrukte téén die onderdrukker. Dit is interessant dat Noordmans in sy meditasie aanvoer die tollenaar het met God as Regter te doen, terwyl die arme bedelaar, Lasarus, met God as Skepper te doen het. Waar die sondaar se gedagte aan God as Regter hom tot skuldbelydenis aanpor, skep die gedagte aan God as Regter by die arme die verwagting tot herstel.

Die arme sou in die laaste sin individueel as 'n enkel, arm mens soos Lasarus verstaan kon word, maar ook kollektief geïnterpreteer kon word as alle armes teenoor alle rykes. Identifikasie met individue en groepe kan plaasvind met die bedoeling om geestelik of materieel te kapitaliseer op die identiteit van die karakter of groep waarmee daar geïdentifiseer word. So kan 'n ryk persoon met die skuldbelydenis van die tollenaar identifiseer om sy rykdom met 'n gesalfde gewete te behou. Dit kan ook gebeur dat iemand hom of haar met die bedelaar vereenselwig om geestelike of materiële voordeel te trek uit die identifikasie met die onderdruktes of benadeeldes. 


\section{B\&S-SKEMA}

Tabel 1: Evalueringshulpmiddel vir'n meer genuanseerde begrip van teologiese stellings oor lewenspeil en die verlossing van sonde

\begin{tabular}{|l|l|l|l|l|}
\hline (i) & (ii) & (iii) & (iv) & (v) \\
\hline IDENTITET & VERHOUDING & OMSTANDIGHEDE & HANDELING & BEWEEGREDE \\
\hline a. God & a. Self & a. Tyd & a. Aktief & a. Inspirasie \\
[Skepper, & b. Familie & [Hemel, & betrokke & [Bronne \& vertroue: \\
Regter, & [biologies, & aarde; & b. Passief & Bybelteks, \\
Trooster...] & ekklesiologies...] & absolute moment, & betrokke & tradisie, \\
b. Mens & c. Vriende(+) & lewenslank] & & konteks...] \\
[Individu, & d.Vreemdelinge( \pm ) & b. Plek & & b. Intellek \\
groep...] & e. Vyande(-) & [Geografie, & & [Begrip, \\
c.Niemenslike & & ouderdom \& geslag, & & logika, \\
skepping & & taal \& kultuur, & & bewyse...] \\
d. Boseen & & posisie in gesin, & & c. Intensie \\
ander magte & & posisie in maatskappy, & & [Ontologies, \\
& emosionele toestand...] & & histories, \\
& & & fenomenologies, \\
& & & & liturgies, \\
& & & & kerugmaties, \\
& & & & missionêr, \\
& & & & apologeties, \\
& & & & emosioneel...] \\
\hline
\end{tabular}

Tabel 2: Vereenvoudigde oorsaaklikheidsverband tussen lewenspeil en die verlossing van sondes Lae lewenspeil Hoëlewenspeil

\begin{tabular}{|c|c|}
\hline $\begin{array}{l}1 \text { [God aktief] } \\
\text { God skape die mis-maakte doelbewus vir die ewige } \\
\text { lewe. } \\
\text { (arme onskuldig) }\end{array}$ & $\begin{array}{l}1 \text { [God aktief] } \\
\text { God skape die ryke doellbemus vir die verderf. } \\
\text { (ryke skuldig) }\end{array}$ \\
\hline $\begin{array}{l}2 \text { [God aktief] } \\
\text { God straf die arme vir sonde (teister die arme tot } \\
\text { gehoorsaamheid). } \\
\text { (ame skuldig) }\end{array}$ & $\begin{array}{l}2 \text { [God aktief] } \\
\text { God seën die ryke met rykdom } \\
\text { (ryke onskuldig) }\end{array}$ \\
\hline $\begin{array}{l}3 \text { [Mens aktief] } \\
\text { Die arme is as gevolg van eie sonde soos luiheid, } \\
\text { sondige besluitneming enlof bloot vanweë die natuurlike } \\
\text { staat waarin die mens verkeer, arm. } \\
\text { (arme skuldig) }\end{array}$ & $\begin{array}{l}3 \text { [Mens aktief] } \\
\text { Die ryke is as gevolg van eie gehoorsaamheid aan die } \\
\text { skeppingsopdrag tot arbeid en/of deugsame optrede } \\
\text { soos sobere spaarsamigheid, ryk. } \\
\text { (ryke onskuldig) }\end{array}$ \\
\hline $\begin{array}{l}4 \text { [Mens aktief] } \\
\text { Die ame is die slagoffer van ander mense se } \\
\text { onregverdige optrede (bv. erfsonde, onderdrukking en } \\
\text { misdlaad). } \\
\text { (ame onskuldig) }\end{array}$ & $\begin{array}{l}4 \text { [Mens aktief] } \\
\text { Die ryke word op ongeoorloofde wyse ryk (bv. deur } \\
\text { misdaad en onderdrukking van ander deur } \\
\text { onregverdige arbeidspraktyke). } \\
\text { (ryke skuldig) }\end{array}$ \\
\hline
\end{tabular}


- $\quad$ Toegepas op MIV en VIGS

'n Teologiese stelling waarin iemand sélf aandui hoe hy of sy MIV as straf op 'n immorele seksuele verlede opgedoen het, verskil van 'n teologiese stelling wat oor iemand anders gemaak word, soos byvoorbeeld die algemene opmerking dat die MI-virus God se straf op die seksuele losbandigheid van ons tyd is. In die eerste geval gaan dit oor iemand wat persoonlik met God worstel. Die persoon sou soortgelyk aan die tollenaar in Lukas 18 diep bewus kon wees van sy of haar ellende. Dit kan vir hierdie persoon bevrydend wees om te ervaar dat God - soos Calvyn dit gestel het - deur 'n ramp sy seën oor hom of haar laat kom. Die algemene opmerking in die tweede geval lyk meer riskant. Wanneer ander mense se morele vlak beoordeel word, is die gevaar groot dat daar 'n selfregverdigende ondertoon kan wees. Die Fariseër in Lukas 18 dank God dat hy nie soos diewe, bedrieërs, egbrekers en die tollenaar is nie (Luk 18:11). Die subjek wat 'n algemene stelling oor die verband tussen MIV en die straf van God maak, loop die gevaar om MIV-positiewe mense te oordeel en om selfregverdigend sy/haar/hul MIV-negatiewe status toe te skryf aan 'n onberispelike lewenstyl.

\subsection{Verhouding}

"Verhouding" het te make met antwoorde op vrae soos: Wat is die gesindheid van die persoon wat 'n teologiese stelling maak teenoor die partye waaroor die stelling gemaak word? Hoe staan die partye wat in 'n teologiese stelling genoem word teenoor mekaar?

Intiem verbonde aan die identiteit van die partye betrokke by 'n teologiese stelling, is die relasie waarin hierdie partye teenoor mekaar staan. Mense kan deur bodem, bloed, beursie en belydenis aan mekaar gebind en van mekaar geskei word. ${ }^{11}$ Die effek van hierdie onderskeie aspekte behoort in die evaluering van teologiese stellings oor lewenspeil en verlossing van sonde verdiskonteer te word. ' $n$ Mens is byvoorbeeld geneig om oor die algemeen positief gesind te wees teenoor vriende en om 'n negatiewe houding jeens vyande te hê.

Dit kan gebeur dat eksponente uit die Bevrydingsteologie of Swart Teologie byvoorbeeld Westerse- of blanke teoloë as vyand ervaar en dus vanuit die staanspoor negatief gesind is teenoor partye wat verbind is met hierdie tradisies. Die neo-Calvinisme neig weer in sommige gevalle om die

\footnotetext{
${ }^{11}$ Daar sou ook ander kategorieë bygevoeg kon word, byvoorbeeld die onderskeid tussen geslagte of ouderdomme, maar dit is veral geskille oor grond (bodem), tussen rasse (bloed), tussen ekonomiese klasse (beursie) en godsdienstige groepe (belydenis) wat uitgeloop het op bloedige geweld tussen mense.
} 
natuur of ander elemente wat die bestaande orde in die samelewingskringe of samelewingsverbande bedreig, as vyand te ervaar.

- $\quad$ Toegepas op MIV en VIGS

Wanneer 'n familielid of vriend die MI-virus opdoen en dit bekend word, kan dit heel moontlik 'n ander lig werp op iemand se ervaring van die invloed van die pandemie op die samelewing as toe MIV en vigs bloot 'n probleem was waarvan deur media-beriggewing kennis geneem is. Daar is baie spesifieke patrone ten opsigte van die wyse waarop bodem (die lande wat die ernstigste geraak word deur die MIV- en vigspandemie is in sub-Sahara Afrika) bloed (die voorkoms van MIV en vigs is byvoorbeeld in Suid-Afrika persentasiegewys laer onder die blankes $(6,2 \%)$ en Kleurlinge $(6,1 \%)$ as onder swartmense $(12,9 \%)$ ), beursie (daar is 'n verband tussen armoede en die verspreiding en impak van MIV en vigs) en belydenis (sommige navorsers wys daarop dat die voorkoms van MIV en vigs in streke in Afrika waar Islam die primêre geloof is laer is as in streke waar die Christelike geloof domineer) in verband staan met die verspreiding en invloed van MIV en vigs (Cohen 2002; Pharaoh \& Schönteich 2003; Van der Walt 2003:2-5; Richter 2003:13).

\subsection{Omstandighede}

"Omstandighede" het te make met antwoorde op vrae soos: Handel die teologiese stelling oor die stand van sake in die hemel of op aarde? Word 'n kortstondige oomblik in die teologiese stelling geïmpliseer, of die historiese verloop van tersaaklike partye se hele bestaan? Watter rol speel die geografiese standplaas, ouderdom en geslag, taal en kultuur, die posisie in die maatskappy, asook die posisie in die gesin en die emosionele toestand van die betrokke partye wanneer 'n stelling gemaak word?

Individue of groepe ervaar dikwels gedurende hul lewensloop op verskillende tye voorspoed en teenspoed. Dit kan gebeur dat 'n individu, selfs in 'n tyd van fisiese nood, geseënd voel en op 'n ander tydstip, wanneer dit lyk of dit goed behoort te gaan, verworpe voel. Veral op die vlak van die bewussyn ervaar 'n mens dikwels oor 'n historiese verloop dat jy soos 'n brander in die see rondgeslinger word deur 'n verskeidenheid van emosies.

In die geval van die sondaar vind die emosie van berou (wat met skuldbelydenis gepaard kan gaan) dikwels in 'n absolute moment of kortstondige oomblik plaas. Waar die emosionele ontroering van ons skuldbelydenis neig om in 'n oomblik plaas te vind, is armoede egter gewoonlik 'n langdurige toestand. Noordmans wys op die verskil tussen 'n kortstondige belydenis en die langdurige lyding van armoede wanneer hy sê 
dat die tollenaar in 'n oomblik met sy mond bely, maar Lasarus getuig met sy hele bestaan dat hy 'n skat in die hemel het.

Lasarus is in sy totale ellende in 'n absolute moment geregverdig voor

God soos die sondaar in 'n kortstondige oomblik van skaamte en ellende voor God geregverdig is. Die tydskategorieë absolute moment en lewenslank uit kolom 3 van die B\&S-SKEMA, het nie bloot met die ervaring van skuld en die oomblik van fisiese nood te make nie, maar ook met die protes teen armoede en sonde. Die protes van die woordvoerder van die arme is - net soos die skuldgevoel van die tollenaar - nie altyd lewenslank volhoubaar nie. Die SuidAfrikaanse geskiedenis van die laaste 20 jaar bied talle voorbeelde van bevrydingstryders en teoloë wat teen Apartheid geprotesteer het en met die ontknoping van die politieke stryd self in politieke, ekonomiese en akademiese magsposisies aangestel is, te midde van groot armoede wat steeds in SuiderAfrika heers.

Nie alleen die rol van tyd behoort bedink te word nie, maar ook die rol van plek. 'n Stelling word vanuit 'n bepaalde posisie (in die mees omvattende sin bedoel) gemaak. Die geografiese ligging, ouderdom en geslag, taal en kultuur, posisie in die gesin, posisie in die maatskappy en selfs in sommige gevalle die emosionele toestand van al die gespreksgenote wat in hierdie ondersoek betrek is, kan van belang wees wanneer hulle teologiese stellings oor lewenspeil en die verlossing van sonde geïnterpreteer word.

\section{- $\quad$ Toegepas op MIVIVIGS}

'n Middelklas, Afrikaanssprekende lidmaat van die NG Kerk wat van sy of haar MIV-positiewe status bewus word, sal deur heeltemal ander uitdagings gekonfronteer word as 'n arm persoon in 'n landelike gebied, waar tradisionele waardes die grondslag van die gemeenskap vorm. In hierdie verband behoort die kerk genuanseerd om te gaan met die uiteenlopende pastorale behoeftes van mense wat geraak word deur MIV en VIGS. Daar behoort tegelykertyd in gedagte gehou te word dat die grootste aantal MIV-positiewe mense in Suider-Afrika in die kategorie van die arm persoon uit die bogenoemde voorbeelde val (Van Dyk 2001:33; Richter 2003:13).

Die verreikende gevolge van die kortstondige oomblik waarin die MIvirus deur seksuele omgang oorgedra word en die langdurige konsekwensie van so 'n kort oomblik, verhoog die emosionele lading wat met die bekamping en hantering van hierdie virus gepaard gaan. Dit kan gebeur dat 'n MIV-positiewe persoon, of 'n persoon met vigs, op 'n dubbele wyse ellende ervaar: tollenaarsellende, die skuldgevoel wat 
gepaard gaan met lewenstylbesluite uit die verlede en bedelaarsellende, die fisiese ontbering wat die siekte veroorsaak. Dit is belangrik dat die troosvolle boodskap van die evangelie aan MIV-positiewe mense in hulle moeilike omstandighede opnuut verkondig sal word. Want juis - op 'n besondere wyse in die Gereformeerde tradisie! - kan ons die Troos van die Evangelie in geloof ons eie maak wanneer ons weet hoe groot ons sonde en ellende is (HK So I, vr \& ant 2). En die persoon wat MIV-positief is, weet dit dikwels die beste van almal. Nie omdat hy of sy méér gesondig het as enige iemand anders nie, maar omdat hy of sy ellende ervaar. Daarom kan mense wat met MIV en vigs lewe op 'n besondere manier - soos Noordmans dit gestel het - as elite uit die skare om Jesus beskou word vanweë hulle omstandighede.

\subsection{Handeling}

"Handeling" het te make met antwoorde op vrae soos: Is God aktief of passief betrokke by die gebeure wat die teologiese stelling oor die verband tussen lewenspeil en die verlossing van sonde veronderstel? Is die mens aktief of passief betrokke by die gebeure wat die teologiese stelling veronderstel?

Wanneer daar gevra word na die aktiewe of passiewe betrokkenheid van God of die mens ten opsigte van die verband tussen lewenspeil en die verlossing van sonde, word daarmee nie bedoel dat óf God óf die mens aktief of passief betrokke is in alle teologiese stellings nie. Dit kan ook én God én die mens wees, of gedeeltelik God en gedeeltelik die mens.

Tabel 2 van die B\&S-SKEMA poog om die oorsaaklikheidsverband tussen lewenspeil en die verlossing van sondes in terme van die aktiewe en passiewe bydrae van God en die mens uit te druk. Nie een van die gespreksgenote sou suiwer binne 'n enkel blok op die tabel geplaas kon word nie. Die tabel is egter handig om klemtone raak te sien, aangesien sommige standpunte op 'n besondere wyse deur bepaalde gespreksgenote benadruk word.

Die beskouing van Noordmans (1980:294-296) soos uiteengesit in sy meditasie De Misdeelden, sou as voorbeeld beskou kon word van die klemtoon soos uiteengesit in ry 1 van tabel 2 van die B\&S-SKEMA. In De Misdeelden skryf Noordmans dat daar 'n onmiddellike verband tussen Lasarus se melaatsheid op aarde en sy saligheid in die hemel is. Hy is noodwendig melaats omdat hy verkies is tot die ewige lewe.

'n Voorbeeld van die klemtoon soos aangetref in ry 2 van tabel 2 van die B\&S-SKEMA word aangetref in Calvyn se siening rakende die wyse waarop God ons tot ons saligheid teister met rampe. Volgens Calvyn kan gelowiges hulle daaraan troos dat geen ramp hulle tref sonder dat God dit 
toelaat en beveel nie. God wil ons deur rampe gehoorsaamheid, nederigheid en geduld leer en in liefde terugroep na Hom. Daarom moet ons geduldig die armoede verdra wat God oor ons pad bring.

In Kuyper se leer van die algemene genade kom die siening soos uiteengesit in ry 3 van tabel 2 van die B\&S-SKEMA voor. Volgens die leer van die algemene genade stuit God die deurwerking van die sonde waaraan die skepping onderworpe is. God gebruik mense om deur hulle kultuurarbeid te help om wanorde en verval te beteuel en in hierdie verband is selfs die ongelowiges in hulle kultuurarbeid medewerkers van God.

Waar Kuyper se leer van die algemene genade op 'n besondere wyse die klemtoon van ry 2 van tabel 2 van die B\&S-SKEMA dra, toon Gutiérrez se Bevrydingsteologie op 'n besondere wyse die nuanse van ry 4: Die grootste oorsaak van armes se armoede is die onregverdige strukture waaraan hulle uitgelewer is. Gutiérrez erken dat elke mens persoonlik 'n sondaar is en dat bevryding van selfsug en sonde nodig is. Maar dit is veral die strukturele aard van sonde wat beklemtoon word en die onmag van die onderdrukte armes wat uitgelewer is aan die ongenaakbare selfsug van ryk lande en individue.

- $\quad$ Toegepas op MIV en vigs

Indien die trant van Noordmans se argumentvoering in sy meditasie $D e$ Misdeelden toegepas word op 'n baba wat met MIV gebore word, sou daar aangevoer kon word dat die baba doelbewus geskape is vir die ewige lewe. Die kind is nie toevallig siek nie, maar - in Noordmans se taal - meer opsetlik geskape as 'n gesonde kind om sy plek in die skepping (die plek van lig rondom die kruis) in te neem.

Indien die trant van Calvyn se argumentvoering rakende God se teistering met rampe tot saligheid op iemand met MIV en VIGS toegepas word, dan beteken dit dat 'n subjek sy of haar MIV-positiewe status kan interpreteer as die wyse waarop God hom of haarl teregwys en straf vir ' $n$ immorele daad of lewenstyl. Die subjek sou kon ervaar dat God hom of haar deur dié virus terugroep na Hom.

Indien die trant van Kuyper se argumentvoering soos uiteengesit in die leer van die algemene genade op die bekamping van die verspreiding van MIV en vigs toegepas word, dan sou dit kon gebeur dat die gebruikmaking van ' $n$ kondoom as die genadevolle werking van God geïnterpreteer word. Deur 'n kondoom te gebruik word die deurwerking van die sonde beteuel. 
Indien die trant van Gutiérrez se argumentvoering, soos uiteengesit in sy weergawe van die Bevrydingsteologie, op die MIV- en vigssituasie toegepas word, blyk die oorsaak vir die grootskaalse ellende in SuiderAfrika te wyte te wees aan onregverdige strukture en magsverhoudinge. Die voorkoms van die Ml-virus staan in noue verband met die voorkoms van armoede. Armoede is volgens Gutiérrez ten diepste te wyte aan onregverdige verhoudinge tussen ryk en arm lande en tussen ryk en arm klasse binne lande. Die meeste mense wat die Mlvirus opdoen, is onskuldige slagoffers van hierdie geweld.

Al die bogenoemde toepassings waarin die oorsaaklikheidsverband tussen iemand se MIV-status en sy/haar/hul skuld en/of onskuld voor God aangebied is, is in 'n sekere sin karikature van die onderskeie gespreksgenote se standpunte. Die bedoeling is nie in die voorafgaande paragraaf om die gespreksgenote se argumente genuanseerd aan die orde te stel nie, maar eerder om neigings wat in hulle perspektiewe ten opsigte van die verband tussen lewenspeil en die verlossing van sonde waargeneem word, toe te pas op die verband tussen mense se MIV-status en hul skuld en/of onskuld voor God.

\subsection{Beweegrede}

"Beweegrede" het te make met antwoorde op vrae soos: Watter bronne word vertrou om teologiese stellings oor die verband tussen lewenspeil en die verlossing van sonde te verantwoord? Wat is die betekenis van die teologiese stelling en watter bewyse word voorgehou om die stelling te ondersteun? Wat is die intensie van alle partye betrokke by 'n teologiese stelling?

Die beweegrede vir 'n teologiese stelling oor lewenspeil of die verlossing van sonde hoef nie noodwendig te spruit uit inspirasie wat verkry word uit 'n bepaalde bron of oortuiging nie, maar kan ook 'n poging van 'n persoon of 'n groep wees om groter begrip te kry vir die omstandighede waarin hierdie persoon of groep hom/haar/hulself bevind. Die logiese samehang en inhoud van dié teologiese stelling sou dan die produk wees van deeglike oorweging en noukeurige formulering van die stelling in 'n poging om uitdrukking te gee aan die verstaansworsteling van die persoon of groep. Die algemene menslike behoefte om te verstaan waarom dinge gebeur, hoe die wêreld in mekaar steek en hoe sake met mekaar in verband staan, word op 'n besondere wyse deur wetenskaplike navorsing vervul. Die rol wat die intellek by die samestelling van teologiese stellings oor die verband tussen lewenspeil en die verlossing van sonde speel, behoort in die evaluering van hierdie stellings in gedagte gehou te word. 
Van besondere belang is die intensie waarmee iemand ' $n$ teologiese stelling oor die verband tussen lewenspeil en die verlossing van sonde maak. In kolom 5 van die B\&S-SKEMA word die toonaard van 'n paar moontlike intensies gelys. Die lys is geensins volledig nie. Dit is ook belangrik om in gedagte te hou dat intensies selde suiwer te bepaal is en ook nie maklik te onderskei is nie. 'n Ontiese formulering kan ter illustrasie tegelykertyd 'n liturgiese- (byvoorbeeld wanneer die liturg sê, Alle mense is sondaars, om tydens die erediens die gemeente aan te moedig tot skuldbelydenis) as 'n kerugmaties-missionêre intensie (bv wanneer 'n sendeling op 'n sendinguitreik aan 'n ongekerstende sê, Alle mense is sondaars, met die bedoeling om 'n skuldbesef by die persoon aan te wakker, as eerste stap tot bekering) hê.

Noordmans poog nie in Zondaar en bedelaar om 'n fenomenologiese beskrywing van die arme en die ryke te gee nie. Wanneer hy aanvoer dat Lasarus se skuld nie in Lukas 16 op die voorgrond is nie, dan bedoel hy nie dat Lasarus, as arm persoon, oor die historiese verloop van sy lewe nog nooit gesondig het nie. Noordmans het 'n krities-kerugmatiese intensie. Die bepaalde intensies van die onderskeie gespreksgenote se bydraes bevestig die belang van beweegrede as evalueringshulpmiddel. ${ }^{12}$

- $\quad$ Toegepas op MIV en VIGS

lemand sou kon steun op 'n Bybelteksgedeelte of op 'n bepaalde tradisie of op 'n opmerking van 'n gesaghebbende persoon om 'n verband te lê tussen iemand anders se MIV-status en skuld en/of onskuld voor God.

Wanneer 'n persoon of groep 'n verband tussen iemand se MIV-status en skuld en/of onskuld voor God lê, kan die beweegrede ook wees om groter begrip te verkry vir die uitdagings waarvoor die MIV-en-vigspandemie ons stel. In hierdie geval sou 'n teologiese stelling kon poog om, met 'n beroep op navorsingsresultate en goed gefundeerde

\footnotetext{
${ }^{12}$ Om slegs vier voorbeelde te noem: Calvyn bied in sy Institusie 'n onderwysing in die Christelike geloof en daarom behoort die besprekingspunt in die Institusie oor hoe ons die teenswoordige lewe en hulpmiddele moet gebruik, binne die groter verband van die derde boek van sy Institusie verstaan te word. Kuyper wil in sy Rede aan die Sosiale Kongres groter helderheid bring oor wat belydende volgelinge van Christus in 1891 te doen staan ten aansien van die sosiale nood van hulle tyd. Gutiérrez tree op polemiese wyse in vir die armes en onderdruktes in sy Liberation Theology. Heyns wil in sy Teologiese Etiek 'n inleiding in die etiek bied en Bosch bied in Transforming Missions 'n oorsig oor die wyse waarop die begrip sending ontwikkel en verander het, sowel as 'n argument dát sending steeds ' $n$ integrale, essensiële deel van die Christelike identiteit uitmaak. Gespreksgenote se teologiese stellings oor die verband tussen lewenspeil en die verlossing van sonde behoort teen die agtergrond van die bedoeling van elke werk waarin hierdie stellings voorkom, verstaan te word.
} 
besinning, die redes vir mense se MIV-status en die verband met hul lewenspeil en lewenstyl voor die aangesig van God aan te spreek. As voorbeeld van hoe die verband tussen mense se MIV-status en skuld deur middel van bewysvoering gelê word, sou Van der Walt (2003:1-3) se besprekingspunt Die geskiedenis van MIV/vigs in Afrika wys op 'n vreemde verhouding tussen Christendom en die epidemie, genoem kon word. Van der Walt beroep hom op 'n artikel van Durand, wat met gebruikmaking van epidemiologiese inligting uit Afrika, verwagte en werklike verspreidingspatrone van die MI-virus met die verspreiding van die Christendom en Islam in Afrika verbind. ${ }^{13}$ Durand meen daar is 'n direkte korrelasie tussen die verspreiding van MIV en vigs en die verspreiding van die Christendom en Islam. Hoe groter die voorkoms van Islam, hoe laer die voorkoms van vigs. Van der Walt maak daaruit die afleiding dat die streng Islamitiese seksuele moraal waarskynlik 'n bydrae gelewer het tot die bekamping van vigs in die Moslemlande. Dit wil volgens hom voorkom asof die kerk en Christendom sy belangrike rol om hierdie moraal- en gedragspatroonverwante siekte te stuit, ernstig misverstaan het. Die opstandingskrag van Christus en die pinksterkrag van die Gees, wat lewens kan vernuwe, is nie teen hierdie epidemie ingespan nie. Die kerk van Christus, skryf Van der Walt, het nie daarin geslaag om sout van die aarde te wees nie. Die gevolgtrekking kan uit Van der Walt se bespreking gemaak word dat die kerk, deur ongehoorsaam te wees aan die opdrag om sout van die aarde te wees, skuld het aan die verspreiding van MIV en vigs. Dit is belangrik om in te sien hoe navorsingsinligting deur Van der Walt aangebied word om uiteindelik by te dra tot ' $n$ teologiese stelling wat gemaak word met betrekking tot die verspreiding van MIV en vigs: Van der Walt se afleiding oor die verband tussen die verspreiding van die MI-virus en die skuld van die kerk staan in 'n direkte verband met die betroubaarheid van Durand se interpretasie van die epidemologiese gegewens oor die verspreiding van die epidemie en die verspreiding van die Christendom en Islam in Afrika.

Wanneer ' $n$ teologiese stelling oor die verband tussen iemand se MIVstatus en sy/haar/hul skuld en/of onskuld voor God gemaak word, speel die intensie waarmee die teologiese stelling gemaak word ook 'n belangrike rol, net soos die inspirasie (agter die stelling) en die intellek (by die verantwoording van die stelling) waarna die voorafgaande

\footnotetext{
${ }^{13}$ Van der Walt (2003:2) verwys na die artikel van M C Durand, Die oplossing van VIGS, Joernaal vir Etiese Medisyne, Vol 3, (1), Oktober 2002.
} 
gedeeltes verwys het. lemand kan byvoorbeeld 'n ontiese stelling maak met 'n missionêre intensie. In die brosjure, VIGS, uitgegee deur die CLF VIGS TRUST (2002) staan daar byvoorbeeld geskryf: "Miskien het jy VIGS gekry deur God se gebod wat seks buite die huwelik verbied te verontagsaam. Maar al is dit so, is daar hoop vir almal wat hulle sonde opreg bely." Die opmerking dat daar hoop is vir almal wat hulle sonde opreg bely, is 'n ontiese formulering wat binne die raamwerk van die CLF-brosjure gerig is aan iemand wat vigs het met 'n pastorale- of moontlik selfs missionêre intensie.

\section{SLOTOPMERKING}

Uiteindelik is al die aspekte wat in die B\&S-SKEMA genoem word, onlosmaaklik verbind. Die bedoeling van die skema is nie om die kompleksiteit van die verband tussen lewenspeil en verlossing van sonde te onderspeel nie, maar juis om dit te beklemtoon. Toegepas op teologiese stellings met betrekking tot MIV en vigs beteken dit om in gedagte te hou: 'n Persoon of groep (identiteit) maak met 'n bepaalde motief (beweegrede) vanuit 'n bepaalde konteks (omstandighede) 'n teologiese stelling oor die verband tussen iemand (met wie hierdie persoon of groep in verhouding staan) se MIV-status en sy/haar/hul optrede of lewenstyl (handeling) en gevolglike skuld of onskuld voor God.

\section{Literatuurverwysings}

Berkhof, H 1981. Bruggen en Bruggehoofden: Een keuze uit de artikelen en voordrachten van prof dr H Berkhof uit de jaren 1960-1981, verzameld en uitgegeven ter gelegenheid van zijn afscheid als kerkelijk hoogleraar te Leiden, in E Flesseman- van Leer, F O van Gennep \& W E Verdonk (reds). Nijkerk: Callenbach.

Bosch, D J 1991. Transforming mission: Paradigm shifts in theology of mission. New York: Orbis Books.

Calvin, J 1981. Institutes of the Christian religion, tr by H Beveridge, 2 vols. Grand Rapids, MI: Eerdmans.

Calvin, J 1996. Calvin's Commentaries. 22-Volume Set, originally printed for the Calvin Translation Society. Reprinted. Grand Rapids, MI: Baker Books.

Commentaries on the first book of Moses called Genesis, tr from the original Latin, and compared with the French edition by J King, M.A., of Queen's College, Cambridge, incubent of Christ's Church, Hull.

Commentaries on the twelve minor prophets. Now first translated from the original Latin by J Owen Vicar of Thrussington, Leicestershire.

Commentary on the book of the Psalms, tr from the original Latin, and collated with the author's French version, by J Anderson, vol first-fourth. Grand Rapids, MI: Baker Books. 
Commentary upon the Acts of the Apostles, edited from the original English translation of $\mathrm{C}$ Fetherstone, by $\mathrm{H}$ Beveridge, ESQ.

Commentary on the Epistles of Paul the Apostle to the Corinthians, translated form the original Latin, and collated with the author's French version by $\mathrm{J}$ Pringle.

Commentary on the Epistles of Paul the Apostle to the Philippians, Colossians, and Thessalonians, translated and edited from the original Latin, and collated with the French version, by J Pringle. Grand Rapids, MI: Baker Books.

Commentaries on the Catholic Epistles, translated and edited by $\mathrm{J}$ Owen, Vicar of Thrussington. Leicestershire.

Cohen, D 2002. Human capital and the HIV epidemic in sub-Saharan Africa, ILO Program on HIV/AIDS and the World of Work, Geneva.

Gutiérrez, G 1988. A theology of liberation: History, politics, and salvation, rev ed, translated and edited by Caridad Inda \& John Eagleson. New York: Orbis Books.

Heyns, J A 1986. Teologiese Etiek, deel 2/1: Sosiale Etiek. Pretoria: NG Kerkboekhandel.

Heyns, J A 1989. Teologiese Etiek, deel 2/2: Sosiale Etiek. Pretoria: NG Kerkboekhandel.

Kuyper, A 1880. Souvereiniteit in eigen kring: Rede ter inwijding van de Vrije Universiteit, den 20ste October 1880 gehouden, in het Koor de Nieuwe Kerk te Amsterdam. Amsterdam: J H Kruyt.

Mofokeng, T A 1983. The crucified among the crossbearers: Towards a black christology. Kampen: Kok.

Mofokeng, T A 1989. The cross and the search for humanity: Theological challenges facing South Africa. Journal of Black Theology in South Africa 3(2), 38-51.

Murray, M 2003. Troos vir bedelaar en sondaar: 'n Teologies-kritiese ondersoek na die verband tussen lewenspeil en die verlossing van sonde in die Gereformeerde tradisie en die betekenis daarvan vir 'n Christelike lewenstyl in Suider-Afrika. DD-proefskrif, Universiteit van Pretoria.

Noordmans, O 1980. Verzamelde Werken, Deel VIII, 15-25; 294-296. Meditaties. Kampen: Kok,

Nürnberger, K 1999. Prosperity, poverty and pollution: Managing the approaching crisis. Pietermaritzburg: Cluster Publications.

Nyerere, K 1995. On the division between rich and poor, in Stackhouse, M L, McCann, D P \& Roels, S J (eds), On moral business: Classical and contemporary resources for Ethics in economic life, 415-417. Grand Rapids, MI: Eerdmans.

Pharaoh, R \& Schönteich, M 2003. AIDS, security and governance in Southern Africa: Exploring the impact. (ISS Paper 65.)

Pierson, H 1891. Gelijkenissen des Heeren. 's-Gravenhage: W A Beschoor.

Richter, L M 2003. The impact of HIV/AIDS on the development of children. Paper presented at the Institute for Security Studies Seminar on HIV/AIDS, vulnerability and children: Dynamics and long-term implications for Southern Africa's security, Pretoria.

Van der Walt, H 2003. MIV/VIGS in Suid-Afrika, Kortbegrip van die epidemie en hoe gemeentes daarop kan reageer. Bloemfontein: CLF-Uitgewers.

Van Dyk, A 2001. HIVAIDS: Care \& counselling: A Multidisciplinary approach, 2nd ed. Cape Town: Pearson Education South Africa.

Wolterstorff, N 1981. Until justice and peace embrace: The Kuyper lectures of 1981 delivered at the Free University of Amsterdam. Kampen: Kok. 